${ }^{\circledR}$ Entomologica Fennica. 29.III.1993

\title{
A new method for collecting quantitative samples of insects associated with decaying wood or wood fungi
}

\author{
Lauri Kaila
}

Kaila, L. 1993: A new method for collecting quantitative samples of insects associated with decaying wood or wood fungi. - Entomol. Fennica 4:21-23.

A trapping method for collecting quantitative samples of insects, especially beetles (Coleoptera) associated with decaying wood or wood fungi, is described. The trap is a modification of the window flight trap, attached to dead tree trunks, preferably close to the basidiocarps of polypores. Sampling during the summer of 1990 in southern Finland showed that large numbers of insects living in decaying wood or polypores can be caught with this method without destroying the habitat. Several threatened species were found during this sampling.

Lauri Kaila, Zoological Museum, P.O. Box 17 (P. Rautatiekatu 13), FIN-00014 University of Helsinki, Finland

\section{Introduction}

Intensive modern forestry has drastically altered the structure of forests (see Heliövaara \& Väisänen 1984 for a review concerning Finnish forests). Only fragments of primaeval forests are found outside the nature reserves in Finland today. One of the most important changes is the decrease in the amount of decaying wood, which is a crucial substrate for many fungi (e.g. Renvall et al. 1991), bryophytes (Andersson et al. 1991) and a great variety of insect species, especially beetles (Coleoptera) (Palm 1955). A large number of these species are included in the Finnish list of threatened animals and plants (Rassi et al. 1992).

Loss of natural habitats is the most important factor leading to extinction of species. An urgent task is the obtaining of information on the particular factors that limit the occurrence of species living in vanishing habitats. For this purpose, quantitative methods must be developed for obtaining comparable samples of insect assemblages in different types of environments. However, there are no universal methods for producing relevant information on the whole insect fauna. Instead, specific sampling methods must be used for different groups of insects.

Among forest insects, species associated with decaying wood or wood fungi form the largest ecological group of declining species (Rassi et al. 1992). Many of these species use the wooddecomposing mycelium of fungi as their source of nutrition instead of the wood itself (Palm 1955). Presumably, polypore-associated insects use the spores or odour of polypore basidiocarps as orientation guides to their breeding substrate. In addition, the basidiocarps support a large variety of insect species, especially Coleoptera and Diptera.

A semi-quantitative method for sampling invertebrates living under the bark of dead trunks was applied by Biström \& Väisänen (1988). They collected all invertebrates found under a certain amount of bark. They studied a total of $91.1 \mathrm{~m}^{2}$ 
bark of various tree species and found, among other invertebrates, 520 specimens belonging to Coleoptera. The sample of the most abundant species, Dendrophagus crenatus Paykull (Cucujidae), included 56 specimens. This method seems, unfortunately, rather ineffective because it is difficult to obtain large enough samples for statistical comparisons. Furthermore, the method should not be widely used because it destroys the microhabitat of the insect species under study.

In this paper I introduce a modified version of a window flight trap designed for sampling insects living in dead tree trunks. The trap can be used in quantitative surveys.

\section{Design of the trunk window trap}

The trap consists of a transparent plastic window $(1.5 \times 200 \times 300 \mathrm{~mm})$, an elastic funnel below the window, and a container (Fig. 1). The funnel is made of plastic cloth and its margin is strengthened with $3 \mathrm{~mm}$ iron wire. The funnel is fastened under the cap of the container with a wire ring sewn into the plastic cuff of the funnel. In one side of the container there is a gauze covered overflow hole to drain out the rain water. A twenty \% aqueous solution of ethylene glycol or sodium chloride was used as a preservative in the container, and a small amount of detergent was added to reduce surface tension.

The trap is fastened to the trunk with two wires, one on the upper side of the window, the other in the margin of the funnel. The margin of the funnel is bent to the shape of the trunk. It is profitable to place the trap close to a basidiocarp of e.g. Fomes fomentarius. If the basidiocarp is large, the window can be wedged in the middle of the basidiocarp. The trap should be checked at intervals of two weeks to one month depending on the habitat, as e.g. in sunny places the liquid can dry out.

\section{Preliminary results}

I used this trap in the summer of 1990 in several localities in southern Finland. A total of 93 traps were placed in five birch forests located about 1$30 \mathrm{~km}$ from each other, in eastern Häme. The

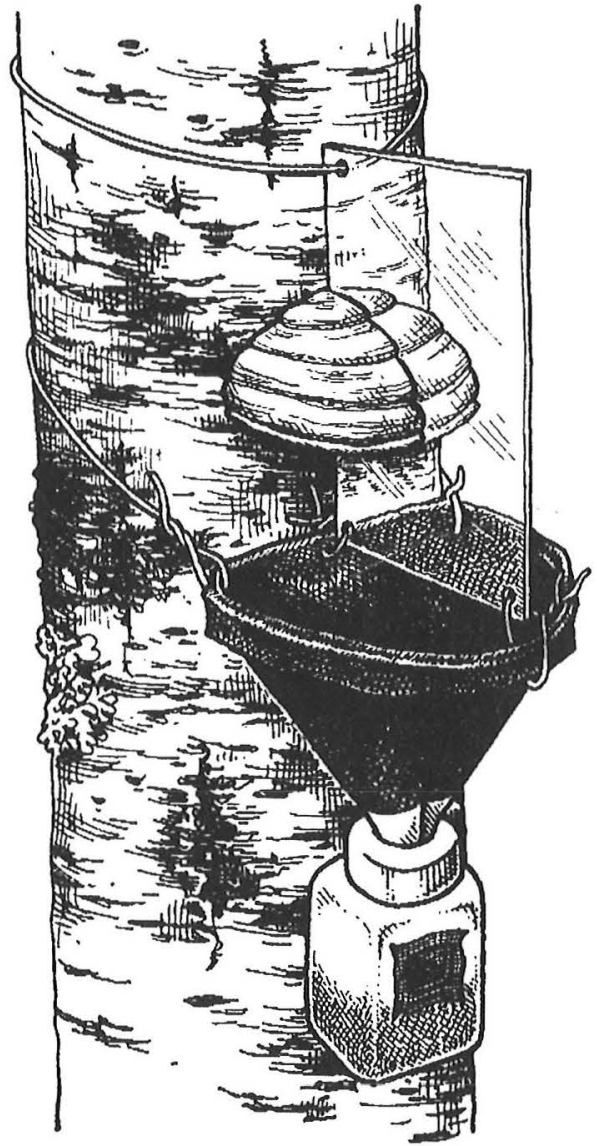

Fig. 1. The trunk window trap attached to a dead birch trunk. The window has been wedged in the middle of a basidiocarp of Fomes fomentarius. For details, see text.

traps were placed close to the perennial basidiocarps of either Fomes fomentarius, Phellinus igniarius or Fomitopsis pinicola. In addition, control traps were fastened on to dead trunks without basidiocarps. All traps were set on birch trunks, most of which were dead. The sampling was performed from the 22 May to the end of September. The aim of this pilot sampling was to check that the method gives adequate samples for further analysis.

The sampling procedure yielded about 13500 specimens of Coleopteran species considered to be associated with decaying wood or wood fungi directly or as predators. The number of species captured in each family are shown in Table 1 . The numbers of the four most abundant beetle 
Table 1. The numbers of captured beetle species considered to be associated with decaying wood or wood fungi. The families are in order of the abundance of the species. The sampling was performed with 93 trunk window traps in eastern Häme, southern Finland during May to September 1990 (12 276 trap days). For further details, see text. Species of Cryptophagidae, Latridiidae, Scydmaenidae and Scaphidiidae were not identified.

\begin{tabular}{|c|c|c|c|}
\hline Family & Species & Family & Species \\
\hline Erotylidae & 5 & Lymexylidae & 1 \\
\hline Staphylinidae & 131 & Mordellidae & 4 \\
\hline Anobiidae & 6 & Lucanidae & 1 \\
\hline Leiodidae & 13 & Tetratomidae & 1 \\
\hline Rhizophagidae & 7 & Endomychidae & 1 \\
\hline Nitidulidae $^{1}$ & 7 & Eucnemidae & 3 \\
\hline Tenebrionidae & 5 & Buprestidae & 2 \\
\hline Cisidae & 10 & Dermestidae & 1 \\
\hline Melandryidae & 6 & Trogositidae & 1 \\
\hline Elateridae $^{2}$ & 9 & Cucujidae & 1 \\
\hline Cerambycidae & 5 & Aderidae & 1 \\
\hline Salpingidae & 5 & Anthribidae & 1 \\
\hline Mycetophagidae & 5 & & \\
\hline Sphindidae & 2 & \multicolumn{2}{|c|}{ Total identified spp. 234} \\
\hline
\end{tabular}

${ }^{1}$ excl. Meligethini, genus Epuraea not identified to species level

${ }^{2}$ excl. species living in the soil

Table 2. Numbers of the four most abundant Coleoptera species associated with wood-decaying polypores and pooled total of decaying wood or polypore associated species.

\begin{tabular}{lrl}
\hline Triplax russica & 2294 & Lordithon lunulatus 948 \\
Dorcatoma robusta & 1648 & Anisotoma humeralis 782 \\
All species & 13500 & \\
\hline
\end{tabular}

species are given in Table 2. Several beetle species included in the Finnish list of threatened species were also found: Carphacis striatus (Olivier), Mycetophagus quadripustulatus (Linnaeus), Triplax rufipes (Fabricius), Dorcatoma substriata Hummel, Peltis grossa (Linnaeus), Tomoxia bucephala Costa, Phytobaenus amabilis F. Sahlberg and Dircaea quadriguttata (Paykull). In addition, the sampling yielded a large number of Diptera, especially Mycetophilidae and Keroplatidae, and some species of the Heteropteran genus Aradus.
Preliminary analyses of the Coleoptera data indicated that the species compositions of samples of the three polypores were consistent but different from each other and the control (these results will be published in detail elsewhere). The knowledge of the effects of the numbers and densities of the basidiocarps of different polypore species on the beetle catches is crucial in interpreting the sources of variation in the samples, and we have already started work on this subject.

Thus, the use of this trapping method in quantitative surveys of decaying wood associated beetles can be recommended because: (1) the microhabitats are not destroyed, (2) large sample sizes can be obtained easily, and (3) the samples collected from similar substrates seem to have a consistent composition, making it possible to study the effects of different ecological conditions, e.g. the structure of the surrounding forest, on the beetle species assemblages.

Acknowledgements. Michael Müller and Jyrki Patomäki are thanked for their kind help in finding suitable sites for the study. Petri Martikainen and Ari Ruuskanen helped in sorting out the material. Tuula Vuorinen is thanked for the picture. I express my sincerest thanks to Yrjö Haila, Petri Martikainen, Samuel Panelius, Pekka Punttila and Juha Siitonen for their valuable comments on the manuscript.

\section{References}

Andersson, L. \& Hytteborn, H. 1991: Bryophytes and decaying wood - a comparison between managed and natural forest. - Holarctic Ecol. 14:121-130.

Rassi, P., Kaipiainen, H., Mannerkoski, I. \& Ståhls, G. 1992: [Report on the monitoring of threatened animals and plants in Finland] (In Finnish). - Komiteanmietintö 1991:30. Ympäristöministeriö, Helsinki.

Biström, O. \& Väisänen, R. 1988: Ancient-forest invertebrates of the Pyhän-Häkki national park in Central Finland. - Acta Zool. Fennica 185:1-69.

Heliövaara, K. \& Väisänen, R. 1984: Effects of modern forestry on northwestern European forest invertebrates: a synthesis. - Acta Forest. Fennica 189:1-32.

Renvall, P., Renvall, T. \& Niemelä, T. 1991: Basidiomycetes at the timberline in Lapland 1. Introduction. - Karstenia 31:1-12.

Palm, T. 1955: Died Holz- und Rinden-Käfer der Süd- und Mittelschwedischen Laubbäume. - Opuscula Entomol. Suppl. 26. 374 pp.

Received 4.XII.1992 